Czestawa Pilarska

Department of Microeconomics

Cracow University of Economics, Poland

\title{
THE IMPORTANCE OF INWARD FOREIGN DIRECT INVESTMENT DURING THE TRANSFORMATION PROCESS IN POLAND WITH A FOCUS ON AMERICAN INVESTMENT
}

\section{Abstract}

The article looks at issues connected with the inflow of foreign direct investment (FDI) to Poland during the period of systemic transformation, i.e. 1990-2012. The author focusses on American investment. She shows that despite the decreased share of American FDI in the total volume of FDI inflows to Poland in recent years, American FDI still plays a significant role in the development of the Polish economy, for example, through its positive impact on the labour market and on the technological modernisation of industries where there is considerable American capital involvement. The author also points out that American companies in Poland are characterised by high sales revenues, a high propensity to export, and by major expenditure on investment.

Keywords: foreign direct investment, transition economies, American FDI, American companies.

\section{Introduction}

The year 2014 marks the $25^{\text {th }}$ anniversary of the commencement of social and economic transformations in Poland and other Central and Eastern European countries (CEECs). These transformations were based on the departure from a centrally planned economy towards a market-driven economy. Whereas Poland was nearly bankrupt in 1989 with a big and inefficient agricultural sector, terrible roads, and poor rail infrastructure, 
today - as pointed out by the authors of the report on Poland published in The Economist - thanks to the economic reforms, the effective use of EU membership, and sensible policies during the financial crisis, which allowed it to be the only EU country to avoid recession, Poland has the chance to enter its "second golden age" (Economist 2014a, p. 5; 2014b, p. 13). The authors of the report stress that Poland utilised the resources from EU structural funds quickly and effectively, and reaped the benefits of improved economic governance and higher transparency. Poland has also managed to deal with corruption better than other CEE countries (such as Romania or Bulgaria), specifically corruption in the public procurement sector. Despite Poland's numerous economic achievements, the report notes that its transformation process is not over yet. Three main problems were mentioned: if Poland wants to progress from being a peripheral economy to a core economy, it must address unemployment, trim the bloated public sector, and also increase corporate and private savings and investment. Furthermore, Poland's development is at an average level, and it may become exposed to the "middle income trap". Avoiding this trap will only be possible if it is able to develop its higher-tech industries and services (Economist 2014b, p. 13). Poland's development of higher-tech, its overcoming of the middle income trap, and the conclusion of the transformation can be aided by wisely distributed capital from abroad, especially in the form of foreign direct investment.

It is emphasised in the literature that in CEE countries (including Poland) direct investment has played a central role in economic restructuring and has supported the transition to a market economy (Sakali 2013, p. 74).

Lucyna Kornecki and Vedapuri Raghavan note that FDI inflows in CEE economies have been a vital factor in the first stage of the privatisation process during the transition period (Kornecki \& Raghavan 2011, p. 19). Kálmán Kalotay claims that FDI in transition economies has played an important role in strengthening the private sector and the emergence of market-oriented entrepreneurship as well as in eliminating macroeconomic distortions inherited from the centrally-planned system (Kalotay 2011 p. 133). Alan A. Bevan and Saul Estrin, in turn, believe that the inflow of FDI into transition economies may facilitate growth, promote technical innovation, and accelerate the transition process by providing for more effective corporate governance and by promoting enterprise restructuring, which is crucial to the transition process (Bevan \& Estrin 2004, p. 776). The aspects of FDI associated with economic growth are also mentioned by Miroslav Mateev, who believes that such investments have gained in 
importance over the past decade as a tool for accelerating the growth and development of economies in transition. According to Mateev, FDI enables CEE countries to raise investment levels above those of domestic savings and forms an important channel for the diffusion of new ideas, technologies, and managerial and other skills (such as marketing and distribution, which were often lacking in the early years of post-communist transition) (Mateev 2008). The positive impact of FDI on transition economies is also noticed by Libor Krkoska. In his opinion, FDI is first and foremost an important source of financing for transition economies as it helps to cover the current account deficit, fiscal deficit (in the case of privatisation-related FDI), and supplements inadequate domestic resources to finance both ownership changes and capital formation. Furthermore, compared to other financing options, FDI also facilitates the transfer of technology, know-how and skills, and helps domestic enterprises to expand into foreign markets (Krkoska 2001, p. 1).

In the case of the Polish economy, numerous empirical papers by a variety of authors have verified the positive impact of FDI on selected macroeconomic parameters such as GDP (Majewska \& Grala 2003, pp. 239-50; Kolasa \& Gradzewicz 2005, pp. 515-28), export, import (Pilarska \& Niezgoda 2004, pp. 163-83), employment (Hybel 2009, pp. 75-83), unemployment (Balcerzak \& Żurek 2010, pp. 7-22), and R\&D expenditure (Marona \& Bieniek 2013, pp. 333-50).

According to UNCTAD, during the transition period Poland attracted the greatest volume of FDI capital among all the countries of the CEE region $^{1}$. The literature stresses that a major role was played by investors from the United States, particularly during the initial stage of the economic transformation. It is noted that American entrepreneurs not only contributed capital to Poland but also brought cutting edge technology, know-how, and business culture, and actively participated in the privatisation process, which considerably accelerated the ongoing transformations (KPMG 2010, p. 3).

The aim of the article is to analyse FDI inflows to Poland during the years 1990-2012 with a focus on American investment, to present the factors determining Poland's attractiveness for American FDI, and to establish the current range of impact of American companies and their investments on the Polish economy.

${ }^{1}$ As at 30 December 2013, Poland was the biggest FDI recipient in the region, having attracted investments valued at USD 252.0 billion. The FDI inward stock of the Czech Republic stood at USD 136.0 billion, while Hungary's was USD 111.0 billion (UNCTAD 2014, p. 209). 


\section{Stages of FDI Inflow to Poland}

From the start of the transformation of its social and economic system, Poland saw rising interest from foreign investors to invest their capital in the Polish economy. The period from the start of the transformation can be divided into four distinct stages: the first covered the years 1990-2000 and saw a continuous and rapidly increasing inflow of direct investment into the Polish economy. Whereas in 1990 Poland's FDI inward stock ${ }^{2}$ stood at USD 109 billion, which was only $0.2 \%$ of GDP, eleven years later, i.e. in 2000, it stood at USD 34,227 billion, or 20\% (UNCTAD 2009, p. 256; UNCTAD 2012 , p. 173). The second stage covered the years 2001-03, which saw a drop in FDI inflows ${ }^{3}$. This was mainly associated with the global situation at that time, i.e. the financial market crisis related to the burst of the Internet bubble. The third stage (2004-07) can be linked to the discounting of the benefits resulting from Poland's accession to the European Union. According to the eclectic theory of John H. Dunning, a country's entry into a large integrative group increases its location advantages (Dunning 1981, pp. 80-81). This is reflected in the fact that FDI inflows to Poland reached the highest levels in the years 2004 and 2007 - USD 12,716 billion and USD 23,651 billion, respectively. The final period, which covered the years 2008-12, is once again linked to the reduced (during 2008-09 and in 2012) inflow of such investments (Table 1), which was caused by external conditions.

During the years 2008-12, Poland's reduced FDI inward stocks were once again associated with the global economic situation. The global crisis, which reached its peak in 2008-09, caused banks and financial institutions to restrict enterprises' access to credit and increase the cost of credit, which considerably hampered the funding of new foreign investment projects (Stawicka 2011, p. 138). Numerous transnational corporations and international enterprises delayed or abandoned implementation of their projects, especially greenfield projects, due to reduced market

\footnotetext{
${ }^{2}$ FDI stock is the value of capital share and reserves (including retained income) with consideration of the net indebtedness of the entities with capital links to the parent enterprise falling to the foreign investor at a specific time, e.g. the end of the year (UNCTAD 2008, p. 249). FDI stock is registered as two items: FDI inward stocks, which are considered as liabilities from foreign direct investments, and FDI outward stocks, which are present as assets. The FDI stock data is disclosed in the book value or as historical cost and reflects prices at the time of the investment (UNCTAD 2008 , p. 250).

${ }^{3}$ FDI inflows are the inflows of capital from the foreign investor to the direct investment enterprise (directly or through other entities with equity links) within a specific time frame (usually year). It covers three elements: equity capital, reinvested earnings, and intra-company loans (UNCTAD 2008, p. 249).
} 
Table 1. Inflow of Foreign Capital to Poland in 1990-2012 by Individual Components (Million USD) with Consideration of the Dynamics

\begin{tabular}{c|c|c|c|c|c}
\hline Year & $\begin{array}{c}\text { Contribution } \\
\text { Withdrawal of } \\
\text { Equity Capital } \\
\text { Share }\end{array}$ & $\begin{array}{c}\text { Reinvested } \\
\text { Earnings }\end{array}$ & $\begin{array}{c}\text { Other Capital, } \\
\text { Mostly Credits }\end{array}$ & $\begin{array}{c}\text { Total Capital } \\
\text { Inflow }\end{array}$ & $\begin{array}{c}\text { Dynamics } \\
\text { Indicator } \\
\text { (Previous Year } \\
=100)\end{array}$ \\
\hline 1990 & 68 & 20 & $\cdot$ & 88 & - \\
\hline 1991 & 268 & 66 & 25 & 359 & 407.6 \\
\hline 1992 & 433 & 154 & 91 & 678 & 188.9 \\
\hline 1993 & 1,109 & 199 & 407 & 1,715 & 252.9 \\
\hline 1994 & 1,096 & 382 & 397 & 1,875 & 109.3 \\
\hline 1995 & 3,159 & 888 & 666 & 3,659 & 195.1 \\
\hline 1996 & 3,116 & 244 & 1,095 & 4,498 & 122.9 \\
\hline 1997 & 3,116 & 25 & 1,767 & 4,908 & 109.1 \\
\hline 1998 & 4,604 & $-264^{\mathrm{a}}$ & 2,025 & 6,365 & 129.7 \\
\hline 1999 & 6,467 & -453 & 1,256 & 7,270 & 114.2 \\
\hline 2000 & 8,813 & -400 & 930 & 9,343 & 128.5 \\
\hline 2001 & 5,301 & $-1,040$ & 1,453 & 5,714 & 61.2 \\
\hline 2002 & 4,283 & $-1,224$ & 1,072 & 4,131 & 72.3 \\
\hline 2003 & 4,561 & -84 & 112 & 4,589 & 111.1 \\
\hline 2004 & 7,321 & 6,210 & -815 & 12,716 & 277.1 \\
\hline 2005 & 4,482 & 3,416 & 2,411 & 10,309 & 81.1 \\
\hline 2006 & 7,382 & 5,753 & 6,741 & 19,876 & 192.8 \\
\hline 2007 & 7,728 & 9,340 & 6,583 & 23,651 & 119.0 \\
\hline 2008 & 9,873 & $-1,116$ & 6,221 & 14,978 & 63.3 \\
\hline $2009 \mathrm{~b}$ & 5,282 & 5,011 & 2,729 & 13,022 & 86.9 \\
\hline 2010 & 4,169 & 7,444 & 2,260 & 13,873 & 106.5 \\
\hline 2011 & 3,369 & 7,197 & 10,054 & 20,620 & 148.6 \\
\hline 2012 & $-3,389$ & 5,705 & 3,744 & 6,060 & 29.4 \\
\hline & & & & & \\
\hline
\end{tabular}

a minus (-) means that the balance sheet losses of the reporting year exceeded the reinvested earnings; ${ }^{b}$ since 2009 , the category "stock and share purchases" has covered real-estate purchases by non-residents; furthermore, the disclosure of "contributions in kind" was discontinued and the "conversions" category is now called "debt financial instruments".

Source: author's own research based on IBRKK (2013, pp. 9-10).

demand. The drop in consumer demand, which had a considerable impact on European Union countries (including the main exporters of foreign capital to Poland), forced enterprises to limit production and reduced or 
often eliminated opportunities to reinvest the profit, which in many cases was small or non-existent. The financial problems of many transnational corporations intensified the process of early repayment of loans obtained by branches from their parent companies and the acquisition of funds from local offices or branches by foreign companies, i.e. reverse loans. In many countries, the global crisis entailed disinvestment, which involves recording the negative value of net capital inflow. Disinvestment occurs when the balance of FDI is negative, which may mean that investors in such countries have decided to withdraw their capital. This situation, which results from the sales of stocks and shares, clearance of credits and loans, and negative reinvestment profit, occurred in 2008 in Ireland (USD -16.4 billion), Italy (USD -10.8 billion), and Finland (USD -1.1 billion), in 2010 in the Netherlands (USD -8.9 billion) and Denmark (USD -7.4 billion), and in 2012 in Belgium (USD -30.3 billion). Disinvestment also affected the economies of two emerging markets in 2012, Slovenia and Slovakia, which saw a considerable outflow of foreign capital leading to a negative FDI inward stock balance (UNCTAD 2014, p. 205).

In Poland, the outflow of FDI capital until $2012^{4}$ was not so drastic because the internal conditions of Poland compared to other countries undergoing economic transformation were very favourable ${ }^{5}$, which kept the Polish economy attractive to investors. However, despite these positive conditions, Poland was unable to maintain a growing FDI trend and in 2008 there was a 37\% drop in the inflow of such investments compared to the previous year. The 2008 drop in FDI value resulted mainly from the general recession in the global economy. The difficulties faced at that time by numerous industries with mostly export-oriented production (particularly the automotive industry) had a negative impact on the financial results of companies with foreign capital and consequently on their investment financing capacity. This situation had a significant impact not only on the value of FDI inflows to Poland, which dropped from USD 23.6 billion in 2007 to USD 14.9 billion in 2008 (a drop of USD 8.7 billion), but also on their structure. Whereas the first two stages of Polish FDI inflow were

\footnotetext{
${ }^{4}$ According to UNCTAD, the net capital inflow to Poland in 2013 was negative and stood at USD -6.0 billion (UNCTAD 2014).

${ }^{5}$ During the years 2008-12, Poland achieved GDP growth. According to Eurostat, the real GDP growth rates for the Polish economy in individual years were as follows: $5.1 \%$ in $2008,1.6 \%$ in $2009,3.9 \%$ in 2010, and $4.3 \%$ in 2011 and 2012. The result achieved by Poland in 2009 is particularly noteworthy, as that was the year when all the European Union countries (UE-27), except Poland, experienced recession. Real GDP for this group of countries in 2009 was $-4.3 \%$, and was even lower (-8.1) for the EU-10 group of countries transforming their economies, http://epp.eurostat.ec.europa.eu/. Accessed: 20 July 2014.
} 
considerably affected by the extensive privatisation under way at that time, from 2004 onwards the share of such investments in the total FDI stream gradually fell. Meanwhile, the role of other components increased, particularly that of reinvested earnings ${ }^{6}$ and capital in transit ${ }^{7}$.

The years 2009-10 were characterised by relative stability in FDI inflows to the Polish economy. The investment streams stood at USD 13 billion and USD 13.9 billion, respectively.

In contrast to the years 2008-2010, in 2011 foreign investors returned to the Polish market in increasing numbers. The reasons for this were mainly that, in addition to hazards, the global economic crisis also created specific opportunities, particularly in non-capital consuming industries. In response to the crisis, foreign companies were searching for opportunities to reduce costs, which caused them to expand their operations, particularly in the domain of Business Process Outsourcing (BPO) and Shared Services Centres (SSC) (Rzeczpospolita 2012a). Poland specialises in these two types of services ${ }^{8}$. It is estimated that one third of the outsourcing centres currently located in Central and Eastern Europe are within Poland. According to Everest's "Market Vista Location Heatmap" report from 2011, which aimed to present the top global locations for off-shoring projects, Poland was in the top five countries most attractive in this regard (along with Brazil, China, the Philippines, and India). The report promoted Poland from the group of emerging markets to the group of developed countries, mainly due to already made investments in the BPO sector, specifically in the field of finance and accounting, and in the IT sector. The newfound interest in investing in Poland was also confirmed by the results of the research conducted by Ernst $\&$ Young and included in its annual report entitled "European Investment Attractiveness". The 2012 edition of this report ranked Poland as the eighth most attractive country to foreign investors (Ernst \& Young 2012, p. 8), whereas the 2013 edition ranked it seventh in terms of numbers of investment

\footnotetext{
${ }^{6}$ The reinvested earnings category refers exclusively to FDI. It does not concern short-term or portfolio investments. According to balance of payments standards, reinvested earnings are treated as if the profit made in the host country was first paid out to the foreign investor, and subsequently reinvested in said country, http://www.nbp.pl. Accessed: 20 July 2014.

${ }^{7}$ The concept of capital in transit refers to the inflow of funds from abroad, which raises the equity value of enterprises with foreign capital operating in the given country, recorded for a given reporting year and invested by said entities in the same reporting year in branches of companies registered abroad, http:// www.nbp.pl. Accessed: 20 July 2014.

${ }^{8}$ At present, there are approximately 350 service centres with foreign capital operating in Poland and their number of employees has surpassed 90,000. The innovative business services sector includes such global companies as IBM, Google, Shell, General Electric, Xerox, Cisco, Energy Micro, and FNC Technologies (Rzeczpospolita 2012b).
} 
projects and third in terms of jobs created thanks to FDI. This high position was due to Poland topping Europe in the number of new investment projects (rising from 121 to 148, by 22.3\%) and number of new jobs (rising from 7,838 to 13,111 , by $67.3 \%$ ) (Ernst \& Young 2012, p. 15).

Despite Poland's high position in the rankings, it was not possible to maintain the growing FDI trend, which fell significantly in 2012 by more than $70 \%$ compared to 2011. Year to year FDI inward stocks went down from USD 14.5 billion to USD 6.0 billion. Poland's weak 2012 result was caused by three main factors (NBP 2014, p. 11): 1) the considerable outflow of capital in transit (USD 5.9 billion) and the associated closure of several special-purpose companies established to transfer (transit) capital ultimately invested in another country in order to optimise fiscal structures; 2) no unitary big transactions, which had had a significant impact on the total value of investment inflows in previous years; 3) the economic crisis in West European countries and the reduced interest of their companies in investments, including foreign investments.

However, the interpretation of the 2012 result should be treated with caution. From the statistical point of view, Poland's result was weak, but an extensive analysis of the FDI inflow structure gives more grounds for optimism. If the investments flowing into Poland are divided into those with no major impact on the host economy (mergers, acquisitions, and capital in transit) and new investments funded with reinvested profit, capital share, and other capital contributions with an actual impact on the economy, e.g. the creation of new jobs and technology transfer, then the drop in FDI is not as deep. By cleaning up the data concerning FDI from capital in transit, it turns out that the inflow of FDI to Poland was USF 11,974 billion and was lower than the inflow calculated in the same manner for the previous year by USD 5,187.5 billion, which means a considerably smaller drop in the actual FDI stream than that suggested by the analysis of FDI with consideration of capital in transit.

Apart from FDI inflows, the National Bank of Poland also monitors Poland's foreign direct investment inward position. This position covers the net carrying value of direct investment companies falling to foreign investors, i.e. the equity value. It is the effectively contributed primary (share or stock) capital and the reserve and supplementary capital, as well as the retained profit minus losses 9 . 
Until 31 December 2012, the total amount invested as FDI in the Polish economy (i.e. the foreign direct investment inward position at the end of 2012) was USD 235,110.7 million (Fig. 1).

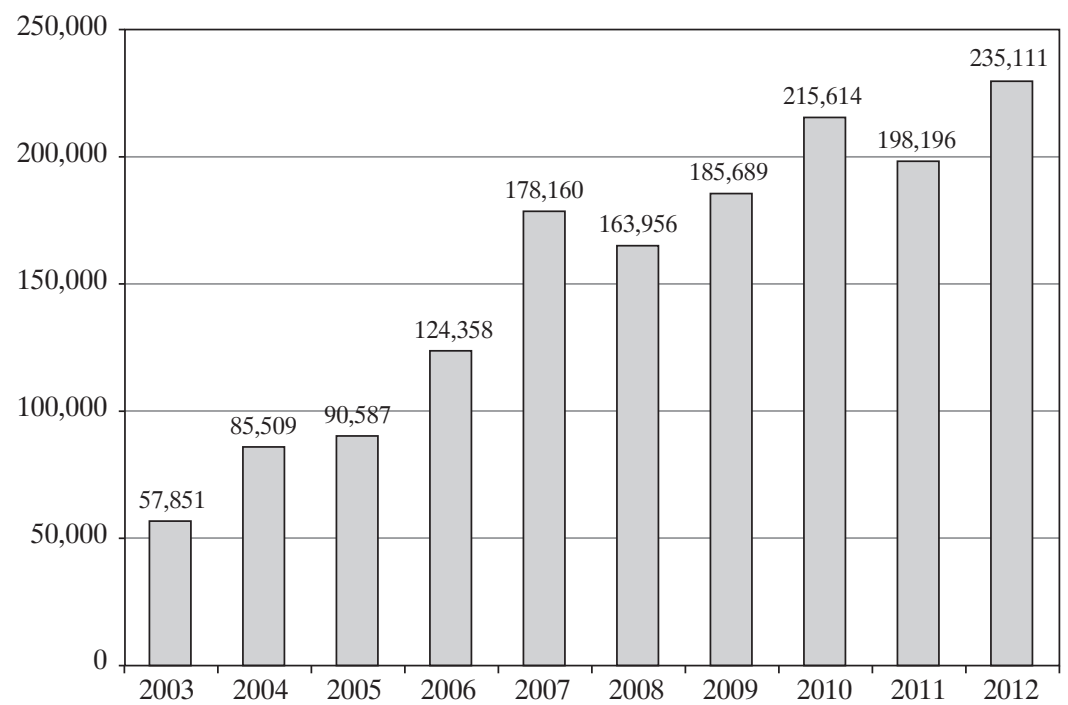

Fig. 1. Foreign Direct Investment Inward Position, 2003-2012 (Million USD)

Source: author's own research based on data from the National Bank of Poland, http://www. nbp.pl. Accessed: 29 July 2014.

At the end of 2012, the highest inward position was recorded for investors with capital involvement in direct investment entities operating in the services sector (USD 137,199.2 million, i.e. 58.4\% of total liabilities), industrial processing (USD 74,425.4 million, i.e. 31.6\%) and construction (USD 12,065.7 million, i.e. 5.1\%).

Thus far, the greatest volume of capital has been invested in Poland by companies from Germany (USD 35,476.5 million, or $15.1 \%$ ), the Netherlands (USD 34,669.0 million - 14.7\%), France (USD 28,935.5 million - 12.3\%), and Luxembourg (USD 24,034.9 million - 10.2\%). An analysis of the geographical structure of FDI flowing into Poland shows that it has remained unchanged for several years. The biggest investors in terms of the foreign investor's country of origin are mainly companies from European countries $(93.5 \%)$, among which European Union countries are dominant (almost 80\%). 
Considering the inward position of US companies, which is most interesting as regards the aims of this study, it may be stated that it developed moderately. According to data from the end of 2012, Poland's liabilities towards American investors stood at USD 10,722.9 million, which accounted for $4.6 \%$ of Poland's total FDI inward position. However, this situation changes diametrically if the analysis covers not the country where the direct investor is registered but rather FDI inward positions classified according to the country where the parent entity is registered. An analysis of Poland's FDI inward position from the perspective of the head office of the parent entity, including the direct investor (headquarters of foreign companies, place of residence of natural persons, or registered locations of private equity funds), shows that the leading foreign investor in Poland is, much like in the case of the investor's country of origin, Germany, followed by the US, with the Netherlands and Luxembourg dropping further down (Fig. 2).

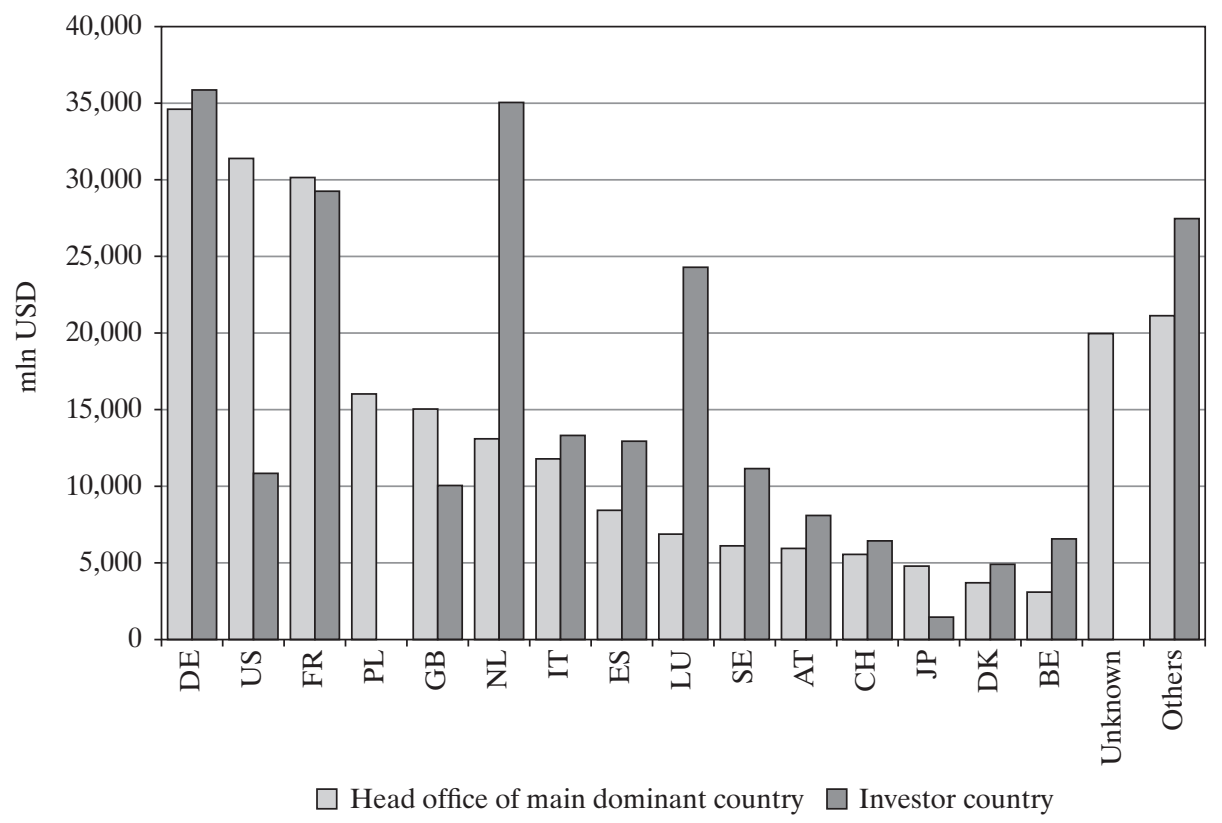

Fig. 2. Foreign Direct Investment in Poland according to the Registered Office of the Investor's Parent Entity (End of 2012)

Source: author's own research based on data from the National Bank of Poland, http://www. nbp.pl. Accessed: 29 July 2014. 
In the case of the Netherlands and Luxembourg, this results from the fact that these countries are often used as the head offices of special-purpose entities in order to reduce the fiscal burden associated with foreign investments ${ }^{10}$. Luxembourg is currently the second largest mutual fund centre in the world after the US ${ }^{11}$.

For the United States, the situation is different. American investors rose to second place because they actually invested in Poland, but their direct investments were usually made through entities established in other European countries, e.g. the Netherlands. It is estimated that US investment in the Netherlands since 2000 has been 14 times higher than US investment in China during the same period. US firms can use the Netherlands as a key export platform and pan-regional distribution hub (Transatlantic 2014, p. vii). In turn, European companies can locate their head office in the USA for reasons of prestige, but also due to the conditions and costs of business activity and access to the American banking system. As shown by the World Bank report that compares the data for 2011, the United States is still the biggest economy in the world and relatively inexpensive compared to other high-income countries (World Bank 2014). In terms of purchasing power parity (PPP), the share of the American economy in global GDP is $17.1 \%$. The United States has been the world's top economy since 1872, when it overtook another superpower - Great Britain. However, the report indicates that China is not far behind. The Chinese economy's percentage share of GDP calculated at PPP was $87 \%$ that of the US in 2011. The IMF forecasts that China is likely to overtake the US this year because China's economy is said to have grown by $24 \%$ between 2011 and 2014 whereas the US economy is expected to expand by only 7.6\% (Giles 2014). As regards the price level index (PLI), the most expensive economies in terms of GDP are Switzerland, Norway, Bermuda, Australia and Denmark, with indices ranging from 210 to 185 (the world price level index is equal to 100) (World Bank 2014, p. 84). The United States ranked $25^{\text {th }}$ in the world, lower than most other high-income economies, including France, Germany, Japan, and the United Kingdom.

\footnotetext{
${ }^{10}$ It is estimated that in order to reduce the fiscal burden, about $40 \%$ of the world's FDI is routed through tax havens such as the British Virgin Islands. In 2011, for instance, 30\% of India's inward direct investment came from Mauritius; $25 \%$ of Brazil's came from the Netherlands; and $60 \%$ of China's came from Hong Kong and the British Virgin Islands (Zucman 2013, p. 1325).

${ }^{11}$ Ibid.
} 


\section{Extent and Impact of US Investment in Poland on the Polish Economy}

As presented by UNCTAD statistics, the United States is the greatest FDI exporter in the world (UNCTAD 2014, p. 209). The value of the FDI stock of American companies at the end of 2013 was USD 6,349.5 billion (USD 1,158.4 billion more in comparison to 2012) and was more than three times greater than the value of the investments of enterprises from the UK, Germany, and France - countries occupying the next places in the ranking of biggest foreign investors in the world.

The countries of Europe are the main targets of American foreign investment. Based on the data from the US Bureau of Economic Analysis (BEA), by the end of 2012 the United States had invested USD 2,477.0 billion in Europe, or over 55\% of total American foreign investment, which, according to the BEA, was USD 4,453.30 billion in 2012. The next positions with regard to capital invested by American companies are occupied by the Latin American countries, with investments of USD 869.3 billion, and countries located in the Asia and Pacific region (USD 651.3 billion).

American investors chose two directions in Europe. On the one hand, they were driven by the market and invested in countries with strong economies and a big local market. This group includes primarily the UK (USD 597.8 billion), followed by Germany (USD 121.2 billion) and France (USD 82.6 billion). On the other hand, American investors also chose smaller European countries that offered favourable fiscal regulations, good geographical locations, and advanced infrastructure. These countries include the Netherlands (USD 645.1 billion), Luxembourg (USD 383.6 billion), Ireland (USD 203.8 billion), Switzerland (USD 130.3 billion), and Belgium (USD 53.8 billion). Most of the enterprises established in these countries are holding companies, which often invest in subsidiary companies in other countries (KPMG 2010, p. 16). The largest portion of American capital was invested in the Netherlands and the UK, which host more than half of the investments made in Europe. A particular role is played by the Netherlands, which received $14.5 \%$ of American investment as at the end of 2012, more than any country in the world receiving FDI capital from the US.

Poland is $16^{\text {th }}$ among the European recipients of American capital. American investors invested a total of USD 14,178 million in Poland, or $0.6 \%$ of all American investment in Europe. Compared to other European countries this is not an impressive result, but it looks much better when compared to the level of investment made in other CEE countries, where 
Poland is the undisputed leader. American entrepreneurs made twice as many investments in Poland as in the Czech Republic or Hungary. As at the end of 2012, these countries received USD 6,389 million and USD 6,014 million, respectively.

An analysis of American investments flowing into Poland shows that their total value grew continuously between 1990 and 2007, when it reached its peak of USD 15,614 million. Thereafter, due to the financial crisis in the global economy, the total value of this investment fell in 2008 to USD 12,489 million. Over the years 2009-11, American investments in Poland were around the level of USD 13 billion, and grew slightly (by 5.4\%) in 2012. Despite the recorded growth, their total value in 2012 was USD 1,436 million less than during the record year of 2007 (Fig. 3).

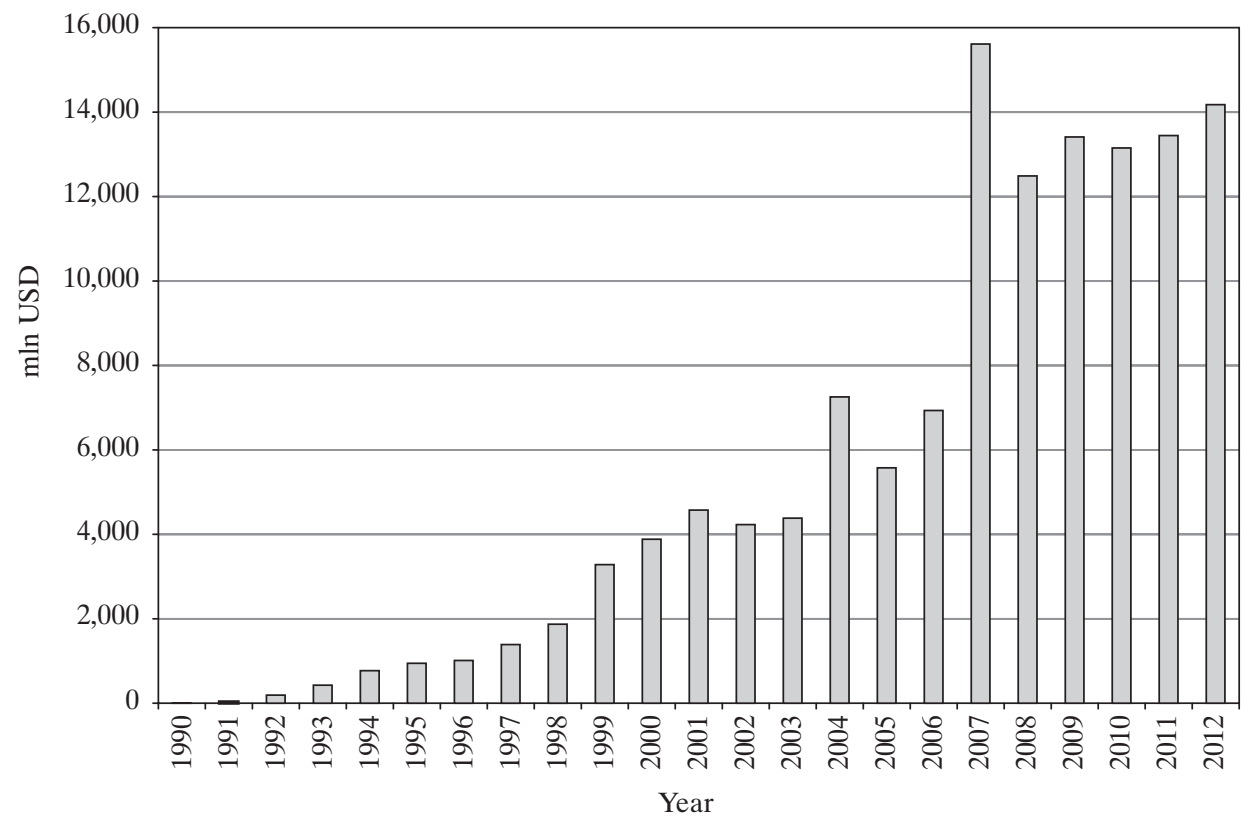

Fig. 3. US Direct Investment Stock in Poland (Million USD)

Source: author's own research based on the US Bureau of Economic Analysis.

It should be noted that the values calculated by the BEA are significantly underestimated. This is due to the fact that the statistics developed by the BEA concern only that portion of American investments made by companies registered in the US. Meanwhile, a large part of US investments 
in Poland are made through holdings and subsidiaries registered in other countries, as previously discussed. For American companies it has often been easier to carry out investments in Poland through subsidiaries, which have operated in Western Europe for many years (KPMG 2010, p. 16) and have an established market position.

Besides the volumes, the BEA also presents the professional structure of American direct investment flowing into Poland. Based on the available data for 2012 (which does not take the item of "Depository Institutions" into account), the biggest share is held by "Manufacturing", which received investment amounting to USD 4,305 million, or $30.35 \%$ of total FDI stock during that year. As regards industry, there was particular investor interest in "Food", which attracted investment of USD 1,611 million, and "Transportation Equipment", with investment of USD 1,138 million. Apart from production, American investors also focused on "Trade" as well as "Finance and Insurance", which saw investment of USD 2,123 million and USD 1,777 million, respectively (Table 2).

The literature notes that American capital played a vital role in the initial economic transformation stage, when the most renowned American corporations entered Poland. In the mid-1990s, the share of American capital in all investments was almost 14\% (KPMG 2010, p. 23). Today, despite systematic growth in the value of American investments in Poland, their share in Poland's total FDI is gradually decreasing, from $12.8 \%$ in 1998 to the current level of $4.6 \%$, according to the aforementioned data of the National Bank of Poland. Despite this drop, American investments continue to play a significant role in the Polish economy. According to the Central Statistical Office (GUS), there were 794 entities with American capital involvement in 2012, 131 of which had foreign capital of over USD 1 billion (GUS 2013, p. 53, 56). The research conducted by KPMG shows that the main factors which determined Poland as an FDI location were, in order of importance: 1) geographical location (almost 90\% of the surveyed companies deemed it attractive), 2) workforce - quality of education, 3) size of the local market, 4) workforce - quality of professional skills, 5) growth potential of the economy, and 6) economic stability (KPMG 2010, p. 63).

According to BEA statistics, employment in companies located in Poland with a majority share of American capital more than doubled in eight years. In 2003, it was 71,300 people, whereas in 2011 such companies were employing 155,900 people. Over $64 \%$ (100,000 people) of the employees of companies with American capital involvement work in the industrial sector. The second largest sector with the share of over $10 \%$ is finance and 


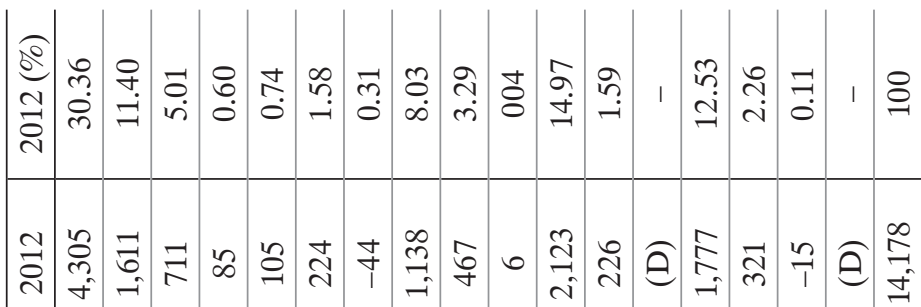

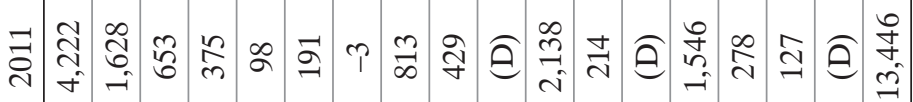

คิ

今

ब

冚孛

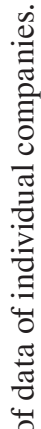

$\frac{\dot{n}}{\frac{\pi}{\sqrt{2}}}$

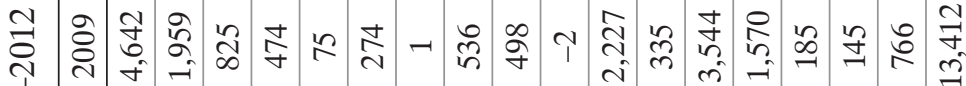

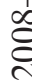

氕

光

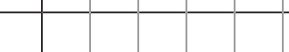

10 ता लेखा

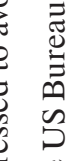

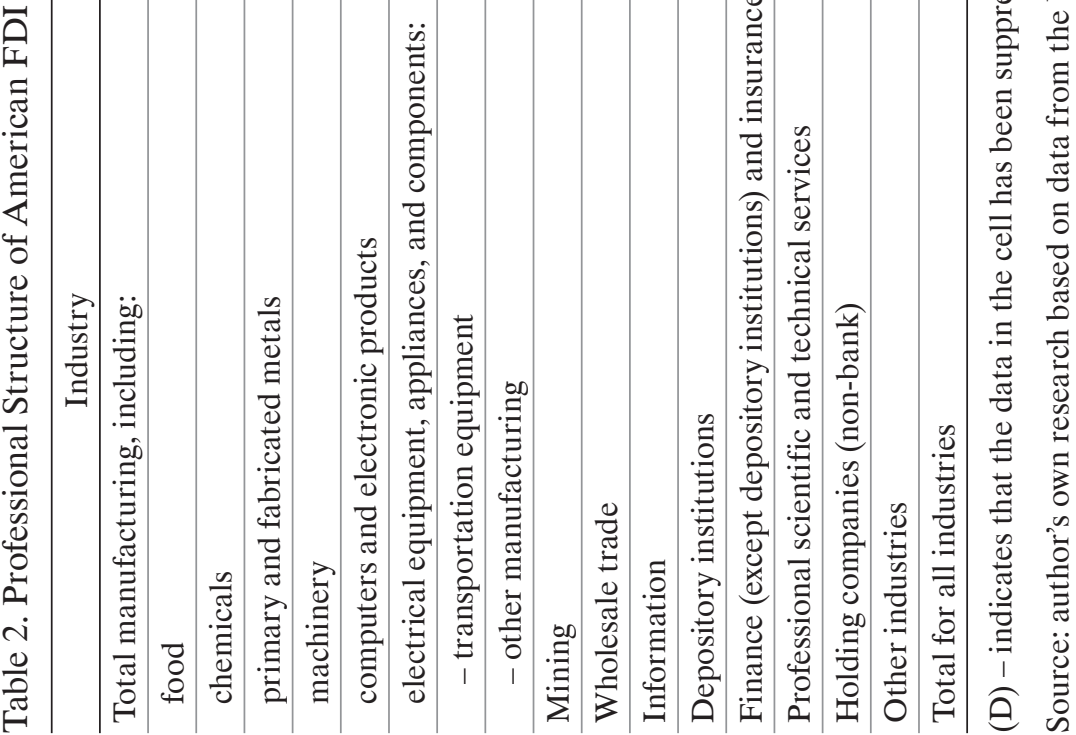




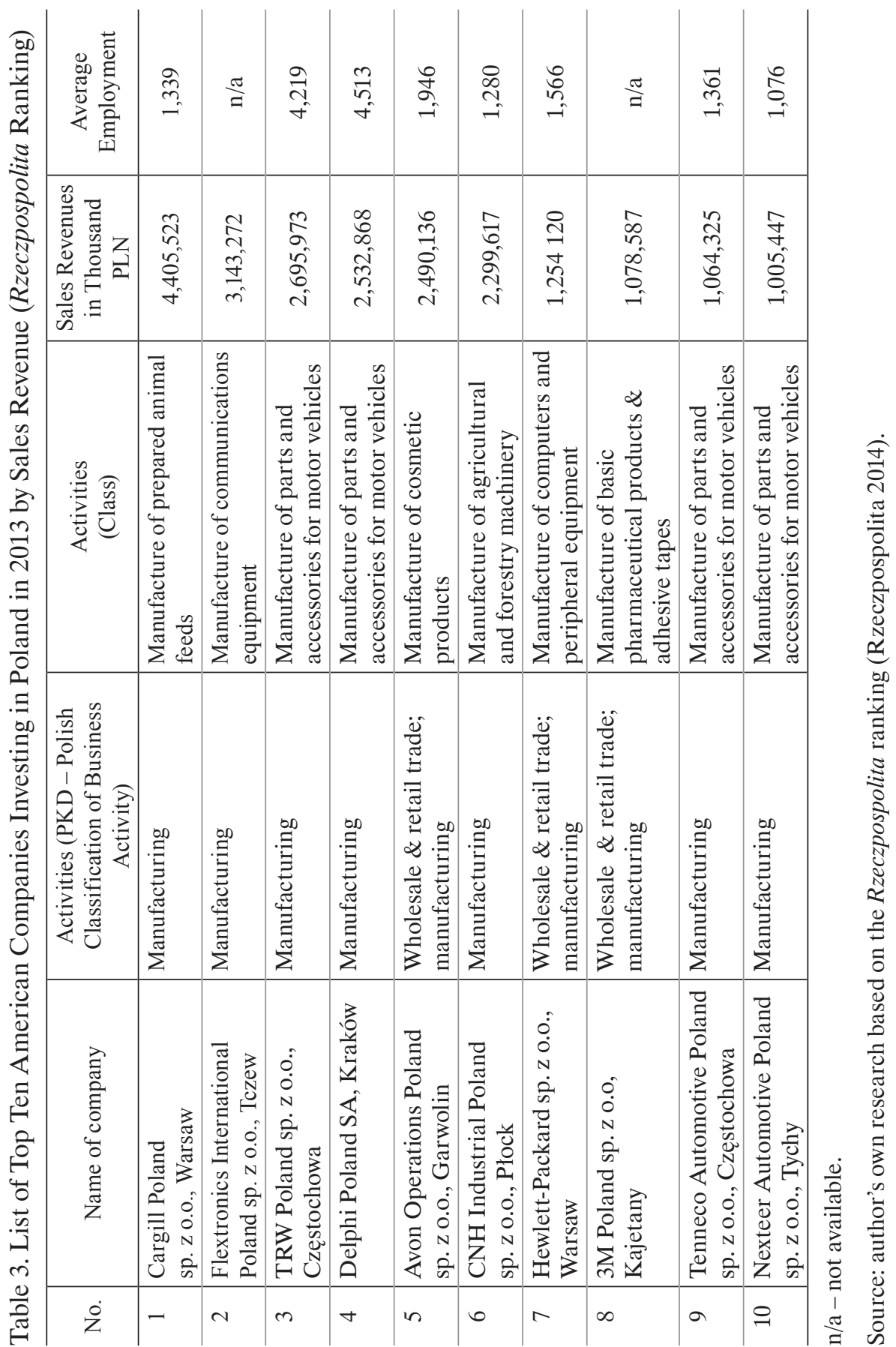


insurance, which employs 15,800 people. Third place goes to trade, which provides employment for 12,200 people $(7.8 \%)$.

Employment in the area of production was dominated by American companies that manufacture means of transport, mainly motor vehicles. This area saw the creation of the total of 34,100 jobs. American companies producing food are also significant employers $(16,500$ people) as are those in the field of chemical products, with 8,800 jobs created.

The list of biggest foreign investors in Poland published annually by the Polish Information and Foreign Investment Agency included 173 American companies, which accounts for $10.8 \%$ of the 1601 companies included on the list in 2013 (PAIiIZ 2013).

The Rzeczpospolita ranking, which classifies companies operating in Poland according to their sales revenue, creating a so-called "Top 500 List" of biggest companies, included several American companies (Rzeczpospolita 2014). The highest sales revenue among the American companies operating in Poland (and included in the "Top 500 List") was PLN 4.4 billion earned by Cargill Poland. The next positions were occupied by Flextronics International Poland and TRW Auto Holdings. Table 3 presents the list of the top ten American companies investing in Poland with the greatest sales revenue in 2013 and their type of business. However, it should be noted that the biggest American investor in Poland (absent from the "Top 500 List") is the automotive company General Motors Manufacturing Poland Sp. z o.o. This enterprise, which is located in a special economic zone in Gliwice, began production in 1998 as one of the most innovative car production plants in Poland. The company currently employs 3,500 people and (according to data for 2011) has a sales revenue of PLN 7.8 billion (KPMG 2013a). In January 2014, the company announced its plan to locate a plant producing a new generation of medium capacity diesel engines in the town of Tychy. Production of the four cylinder 1.6-litre diesel engines is due to commence in 2017. The value of this investment in the factory is estimated at EUR 250 million. This is the largest investment in the plant's history, and it will include the construction of new buildings and structures and the installation of new production lines. The maximum total production capacity of the plant will be 200,000 per year (Puls 2014).

The American companies presented in Table 3 do not just have high sales revenue. Delphi Poland, in fourth place, also has a high level of investment expenditure. Rzeczpospolita's 2013 ranking (Rzeczpospolita 2014) placed this company first in Poland in terms of incurred investment expenditure, as it had allocated PLN 4,123.3 million to investment in 2012. 
American companies are also among the biggest exporters in Poland. In 2013, the share of exports in the sales revenue of the American automotive company Autoliv Poland sp. z o.o. was 99.99\% (Rzeczpospolita 2013, p. 35), and it still came second after the Japanese Toyota company, which had a $100 \%$ share of exports in sales revenue. Apart from Autoliv Poland, the biggest exporters also include other American vehicle manufacturer, such as TRW Polska sp. z o.o. (with a $90.31 \%$ share of exports in sales revenue), Tenneco Automotive Polska sp. z o.o. (86.30\%), and TI Poland sp. z o.o. $(84.09 \%)$.

It should be noted that the foreign direct investment made by American companies is an important channel for the transfer of cutting edge technology. When foreign investors enter Polish companies, they break through those companies' internal barriers to competitiveness. They raise their competitiveness by contributing capital, technological solutions that are often unknown in Poland, qualifications, as well as innovative management, organisation, distribution, and marketing methods.

The appearance of well-known and big American corporations in Poland is very important to the economy. The reasons for this include the multiplier effect, which means that when big corporations invest in Poland they attract numerous partners and collaborators. This was the case with one of the suppliers of General Motors, which invested USD 30 billion in a shock absorber plant in Krosno due to the earlier investment by General Motors. The investments made in Poland by the Korean company LG Philips for the manufacture of LCD screens led to another high-tech investment by the American company 3M, which decided to build a production plant in Wrocław to manufacture the special, patented optical foil used in Phillips screens. This factory was initially to employ approximately 500 people, and the value of the investment was estimated at USD 50 million (Maciejewicz 2005). Today, $3 \mathrm{M}$ employs more than 1700 people in Poland, and the total capital invested by the company in the Polish economy is estimated at USD 350 million (Wprost 2013).

It should also be noted that the impact of American foreign capital on the Polish economy is not just limited to enterprises with a share of said capital, since the capital undergoes the deflection effect and has a considerable impact on domestic companies too. The need for competitiveness makes Polish enterprises undergo positive changes, encourages them to modernise their production potential, and stimulates them to introduce new technologies and changes to management. 


\section{Conclusion}

The above analysis leads to the conclusion that the development of foreign direct investment in Poland is very dynamic. From the outset of the transformation process until the end of 2012, foreign investors invested a total of USD 235.1 billion in Poland.

However, FDI inflow to Poland was imbalanced during the period under analysis, i.e. the years 1990-2012. Apart from in the initial period, the fastest growth in FDI inflow was recorded in 2004, which was associated with the discounting of the benefits related to Poland's accession to the European Union. The lowest growth was in the years 2001, 2008, and 2012, which was directly related to the recession in the global economy.

The analysis also shows that a major role in FDI inflow to Poland was played by American companies, which invested over USD 14 billion in the Polish economy. Besides the stock volume, which allowed the gap between the desired investment level and the amount of domestic savings to be reduced, American investors were also active in transforming the Polish economy into a market economy, as they actively participated in the privatisation of Polish companies, particularly during the early stages of the transformation. Their positive influence on the Polish economy is also visible in the area of employment, through the creation of new jobs, and in the technological modernisation of selected industrial sectors. American investment in Poland over 20 years, particularly investment in the automotive industry, has made Poland one of the biggest producers of vehicles and vehicle parts and components in Central and Eastern Europe (KPMG 2013b, p. 154).

The economic results achieved by American companies in the form of high sales revenues and wide-ranging exports and investments are also noteworthy.

The research conducted among American investors shows that the Polish economy is an attractive place to invest capital. However, those investors also mentioned the barriers to doing business, including the low quality of the road infrastructure, inefficient administration and bureaucracy, and the complicated fiscal system (KPMG 2010, p. 63). The elimination of such barriers, an active state policy towards foreign investors, and the effective work of such institutions as the Polish Information and Foreign Investment Agency or the American Chamber of Commerce, should increase the volume of American FDI flowing into Poland. This is particularly important given that recently American investment has declined as a proportion of 
total direct investment flowing into Poland. In this respect, some help may be provided by the gradually improving economic situation throughout the world. The global experience shows that FDI flows are sensitive to crises. Recessions see major FDI fluctuations and the outflow of FDI from emerging markets towards more mature economies. The current post-crisis stimulation of the global economy reduces new investment risk and creates an incentive for companies to return and increase their activity in Central and East European countries, including Poland.

\section{Bibliography}

Balcerzak, A. P. and Żurek, M. (2010) "Analiza wpływu bezpośrednich inwestycji zagranicznych na PKB i stopę bezrobocia w latach 1995-2010 za pomocą modelu VAR" [Analysis of the impact of foreign direct investment on GBP and unemployment in 1995-2010 using a VAR model]. Almanacs of the University of Computer Sciences and Economics in Olsztyn Nos 1-2, pp. 7-22. Olsztyn: WSIiE TWP.

Bevan, A. A. and Estrin, S. (2004) "The Determinants of Foreign Direct Investment into European Transition Economies". Journal of Comparative Economics 32(4): 775-87.

Dunning, J. H. (1981) International Production and the Multinational Enterprise. London: Allen \& Unwin.

Economist (2014a) "Special Report Poland. A Golden Opportunity". The Economist, 28 June.

Economist (2014b) “Europe's Unlikely Star. Poland's Second Golden Age”. The Economist, 28 June.

Ernst \& Young (2012) "Growth, Actually. Ernst \& Young's 2012 European Attractiveness Survey", http://www.ey.com/GL/en/Issues/Business-environment/2012-European-attractiveness-survey. Accessed: 22 July 2014.

Ernst \& Young (2013) "Ernst \& Young's Attractiveness Survey. Europe 2013. Coping with the Crisis, the European way", http://www.ey.com/Publication/vwLUAssets/ European-Attractiveness-Survey-2013/\$FILE/European-Attractiveness-Survey-2013. pdf. Accessed: 23 July 2014.

Giles, Ch. (2014) "China Poised to Pass US as World's Leading Economic Power this Year", http://www.ft.com/cms/s/0/d79ffff8-cfb7-11e3-9b2b-00144feabdc0.html\#axzz38 my1ZJDK. Accessed: 29 July 2014.

GUS (2013) "Economic Activity of Entities with Foreign Capital in 2012". Statistical Information and Elaborations. Warsaw: Central Statistical Office.

Hybel, J. (2009) "Wpływ bezpośrednich inwestycji zagranicznych na rynek pracy w Polsce" [The impact of foreign direct investment on the labour market in Poland]. Academic Papers of the Warsaw University of Life Sciences No. 79, pp. 75-83. Warsaw: SGGW.

IBRKK (2013) "Inwestycje zagraniczne w Polsce 2009-2011" [Foreign investment in Poland, 2009-2011]. Warsaw: Institute for Market, Consumption and Business Cycles Research.

Kalotay, K. (2011) "Patterns of Inward FDI in Economies in Transition" in R. Vos and M. Koparanova (eds) Transition and Economic Diversification: Globalization and 
Economic Diversification Policy Challenges for Economies in Transition. Oriental Longman and Zed Hope, pp. 133-154, http://www.bloomsburycollections.com/book/ globalization-and-economic-diversification-policy-challenges-for-economies-intransition/. Accessed: 17 July 2014.

Kolasa, M. and Gradzewicz, M. (2005) "Napływ bezpośrednich inwestycji zagranicznych a wzrost gospodarczy" [The inflow of foreign direct investment and economic growth]. Ekonomista 4: 515-28.

Kornecki, L. and Raghavan, V. (2011) "Inward FDI Stock and Growth in Central and Eastern Europe. Academic Research Centre of Canada". Review of Economics \& Finance: $19-30$.

KPMG (2010) "20 Years of American Investment in Poland. Report of the American Chamber of Commerce in Poland and KPMG". Warsaw: KPMG.

KPMG (2013a) "Condition of the Automotive Industry and Its Role in the Polish Economy". Warsaw: KPMG.

KPMG (2013b) "Automotive Industry. Yearbook 2013”. Warsaw: KPMG.

Krkoska, L. (2001) "Foreign Direct Investment Financing of Capital Formation in Central and Eastern Europe". EBRD Working Paper Vol. 67.

Maciejewicz, P. (2005) "500 miejsc pracy od 3M" [500 jobs from 3M]. Gazeta Wyborcza, 19 December.

Majewska, M. and Grala, J. (2003) "Zagraniczne inwestycje bezpośrednie a wzrost gospodarczy Polski" [Foreign direct investment and Poland's economic growth] in W. Karaszewski (ed.) Bezpośrednie inwestycje zagraniczne w Polsce [Foreign direct investment in Poland]. Toruń: Nicolaus Copernicus University, pp. 239-50.

Marona, B. and Bieniek, A. (2013) "Wykorzystanie modelu VECM do analizy wpływu bezpośrednich inwestycji zagranicznych na gospodarkę polską w latach 1996-2010" [Use of a VECM model to analyse the impact of direct foreign investment on the Polish economy, 1996-2010]. Acta Universitatis Nicolai Copernici. Ekonomia XLIV No. 2, pp. 333-50.

Mateev, M. (2008) "Determinants of Foreign Direct Investment in Central and Southeastern Europe: New Empirical Tests". Eighth Global Conference on Business \& Economics, Florence, 18-19 October.

NBP (2014) "Polskie i zagraniczne inwestycje bezpośrednie w 2012 r." [Polish and foreign direct investment, 2012]. Warsaw: National Bank of Poland.

PAIiIZ (2013) "List of Major Foreign Investors in Poland 2013". Warsaw: Polish Information and Foreign Investment Agency, http://www.paiz.gov.pl/publications/ foreign_investors_in_poland. Accessed: 31 July 2014.

Pilarska, $\overline{\mathrm{C}}$. and Niezgoda, J. (2004) "Makroekonomiczne konsekwencje napływu bezpośrednich inwestycji zagranicznych do Polski" [Macroeconomic consequences of the inflow of foreign direct investment to Poland] in Transformacja. Integracja. Globalizacja. W poszukiwaniu modelu rozwoju gospodarczego Polski [Transformation. Integration. Globalisation. In search of a model of economic development for Poland]. Kraków-Tarnów: Cracow University of Economics, Małopolska School of Economics in Tarnów, pp. 163-83.

Puls (2014) “GM zainwestuje 250 mln EUR w Tychach" [GM to invest 250 million EUR in Tychy]. Puls Biznesu, 11 February. 
Rzeczpospolita (2012a) "Inwestycjom pomaga kryzys gospodarczy. Cięcie kosztów nakręca rozwój ustug dla biznesu" [The economic crisis helps investment. Cost-cutting catalyses the development of services for business]. Rzeczpospolita, 5 October.

Rzeczpospolita (2012b) "Centra przyciągają inwestorów" [Centres attract investors]. Rzeczpospolita, 5 October.

Rzeczpospolita (2013) "Lista 500. Edycja 15" [The top 500 list. Edition 15]. Rzeczpospolita, 24 April.

Rzeczpospolita (2014) “Lista 500. Edycja 16" [The top 500 list. Edition 16]. Rzeczpospolita, 23 April.

Sakali, C. (2013) "Determinants of Foreign Direct Investment (FDI) in Bulgaria: An Econometric Analysis Using Panel Data”. Journal of Economics and Business XVI(1): 73-97.

Stawicka, M. K. (2011) "Wpływ światowego kryzysu na atrakcyjność gospodarek Unii Europejskiej w zakresie pozyskiwania bezpośrednich inwestycji zagranicznych, ze szczególnym uwzględnieniem Polski” [The impact of the global crisis on the attractiveness of European Union countries as regards foreign direct investment, with particular reference to Poland]. Studies and Papers of the College of Management and Finance of the Warsaw School of Economics No. 108. Warsaw: SGH.

Transatlantic (2014) "The Transatlantic Economy 2014. Annual Survey of Jobs, Trade and Investment between the United States and Europe”. Center for Transatlantic Relations - Johns Hopkins University, Paul H. Nitze School of Advanced International Studies, No. 1.

UNCTAD (2008) "World Investment Report 2008. Transnational Corporations and the Infrastructure Challenge". New York and Geneva: UNCTAD.

UNCTAD (2009) "World Investment Report 2009. Transnational Corporations, Agricultural Production and Development". New York and Geneva: UNCTAD.

UNCTAD (2012) "World Investment Report 2012. Towards a New Generation of Investment Policies". New York and Geneva: UNCTAD.

UNCTAD (2014) "World Investment Report 2014. Investing in the SDGs: An Action Plan”. New York and Geneva: UNCTAD.

World Bank (2014) "Purchasing Power Parities and Real Expenditures of World Economies. Summary of Results and Findings of the 2011 International Comparison Program". Washington DC: International Bank for Reconstruction and Development / The World Bank.

Wprost (2013) "3M finalistą FDI Poland Investor Awards" [3M a finalist in the FDI Poland Investor Awards]. Wprost, 21 October.

Zucman, G. (2013) "The Missing Wealth of Nations: Are Europe and the US Net Debtors or Net Creditors?”. Quarterly Journal of Economics 128(3): 1321-64. 


\section{Abstract}

\section{Znaczenie napływu bezpośrednich inwestycji zagranicznych dla procesu transformacji systemowej w Polsce ze szczególnym uwzględnieniem inwestycji amerykańskich}

$\mathrm{W}$ artykule poruszono zagadnienie związane z napływem bezpośrednich inwestycji zagranicznych (foreign direct investment - FDI) do Polski w latach 1990-2012. Szczególną uwagę poświęcono inwestycjom amerykańskim. Wykazano, że pomimo spadku udziału amerykańskich FDI w ostatnich latach w całościowym wolumenie napływu bezpośrednich inwestycji zagranicznych do Polski, odgrywają one istotną rolę w rozwoju polskiej gospodarki, m.in. poprzez pozytywne oddziaływanie na rynek pracy oraz technologiczne unowocześnienie tych branż, w których widoczne jest znaczne zaangażowanie amerykańskiego kapitału. Ponadto amerykańskie przedsiębiorstwa obecne w Polsce cechują się wysokimi przychodami osiąganymi ze sprzedaży, wysoką skłonnością do eksportu oraz wydatkami ponoszonymi na inwestycje.

Słowa kluczowe: bezpośrednie inwestycje zagraniczne, gospodarki w procesie transformacji sytemowej, amerykańskie BIZ, amerykańskie przedsiębiorstwa. 